\title{
Amsacrine Lactate
}

National Cancer Institute

\section{Source}

National Cancer Institute. Amsacrine Lactate. NCI Thesaurus. Code C96771.

The lactate form of amsacrine, an aminoacridine analog and topoisomerase II inhibitor, with antineoplastic activity. Although the exact relationship between DNA binding and its activity has yet to be fully elucidated, amsacrine intercalates DNA through its acridine moiety, and its nonintercalative headgroup impedes topoisomerase II activity, augmenting enzyme-mediated DNA cleavage and resulting in DNA double-strand breaks. This ultimately induces programmed cell death. 